\title{
FLUORESCENT ANTIGLOBULIN STUDIES IN LEUKOPENIC AND RELATED DISORDERS *
}

\author{
By PAUL CALABRESI, $†$ EARL A. EDWARDS AND ROBERT F. SCHILLING \\ (From the Department of Medicine and the State Laboratory of Hygiene, University of $W$ is- \\ consin Medical School, Madison, Wis.)
}

(Submitted for publication May 11, 1959; accepted June 12, 1959)

Increasing interest in the search for antileukocyte factors in clinical syndromes characterized by leukopenia has been evident in recent years (1-6). The demonstration of what appear to be auto-antibodies in idiopathic thrombocytopenic purpura (7-9) and acquired hemolytic anemia (10-12) has, by analogy, directed attention to the possibility of a similar mechanism operating in certain leukopenic conditions $(1-6,13)$. Similarly, the effects of drug sensitivity have been recognized to affect any or all of the three formed elements of the peripheral blood (14-20). Evidence has also been presented that in patients requiring multiple transfusions, powerful leukocyte antibodies may be produced and give rise to undue reactions (2123). Finally, the reported occurrence of antileukocyte substances in patients with aleukemic leukemia and Hodgkin's disease presents another area for further investigation $(2,24-27)$.

The lack of a simple, reproducible, reliable technique for the detection of leukocyte antibodies still constitutes a limiting factor in this branch of immunohematology $(3,25,28,29)$. With the development of fluorescein-labeled antibodies (30), a new tool has become available for the study of immune reactions. This paper deals with the application of this method in the search for antileukocyte factors in several disorders, with special emphasis on rheumatoid arthritis, Felty's syndrome and systemic lupus erythematosus (SLE). A preliminary report has been presented (31).

\section{MATERIALS AND METHODS}

Blood smears. Capillary blood from normal individuals of varying $\mathrm{ABO}$ and $\mathrm{Rh}$ blood types was used. Smears

* Supported in part by research funds from the National Cancer Institute, United States Public Health Service, Bethesda, Md.

$\uparrow$ Field Investigator, National Cancer Institute (FIDB). Present address: Department of Internal Medicine, Yale School of Medicine, New Haven 11, Conn. prepared by the slide method were immediately fixed in 95 per cent ethanol for 45 minutes, rinsed in distilled water and dried before using.

Human sera. Sera from 112 individuals were obtained. When not tested within 24 hours from the time they were drawn, they were stored at $-20^{\circ}$ C. until used. Twenty laboratory workers served as normal controls. All the patients studied were examined by at least one of

TABLE I

Results of test on sera of 112 individuals studied

\begin{tabular}{|c|c|c|c|}
\hline \multirow[b]{2}{*}{ Clinical diagnosis } & \multirow{2}{*}{$\begin{array}{l}\text { Total } \\
\text { no. of } \\
\text { cases }\end{array}$} & \multicolumn{2}{|c|}{$\begin{array}{l}\text { Nuclear leukocyte } \\
\text { fluorescence }\end{array}$} \\
\hline & & Positive & Negative \\
\hline $\begin{array}{l}\text { Systemic lupus erythema- } \\
\text { tosus }\end{array}$ & 15 & 15 & 0 \\
\hline $\begin{array}{l}\text { Rheumatoid arthritis } \\
\text { Felty's syndrome } \\
\text { Uncomplicated }\end{array}$ & $\begin{array}{l}10 \\
13\end{array}$ & $\begin{array}{r}10 \\
2\end{array}$ & $\begin{array}{r}0 \\
11\end{array}$ \\
\hline $\begin{array}{l}\text { Periarteritis nodosa } \\
\text { Serum sickness } \\
\text { Erythema nodosum } \\
\text { Rheumatic fever and chorea } \\
\text { Discoid lupus }\end{array}$ & $\begin{array}{l}1 \\
1 \\
1 \\
3 \\
2\end{array}$ & $\begin{array}{l}0 \\
0 \\
0 \\
0 \\
0\end{array}$ & $\begin{array}{l}1 \\
1 \\
1 \\
3 \\
2\end{array}$ \\
\hline $\begin{array}{l}\text { Hyperglobulinemia } \\
\text { Laennec's cirrhosis } \\
\text { Bronchogenic carcinoma } \\
\text { Multiple myeloma }\end{array}$ & $\begin{array}{l}3 \\
1 \\
3\end{array}$ & $\begin{array}{l}0 \\
0 \\
0\end{array}$ & $\begin{array}{l}3 \\
1 \\
3\end{array}$ \\
\hline $\begin{array}{l}\text { Asthma (on steroids for } \\
3 \text { years) }\end{array}$ & 3 & 0 & 3 \\
\hline Multiple transfusions & 4 & 0 & 4 \\
\hline $\begin{array}{l}\text { Idiopathic thrombo- } \\
\text { cytopenic purpura }\end{array}$ & 5 & 0 & 5 \\
\hline $\begin{array}{l}\text { Granulocytic leukemia } \\
\text { Aleukemic } \\
\text { Leukemic }\end{array}$ & $\begin{array}{l}3 \\
7\end{array}$ & $\begin{array}{l}0 \\
0\end{array}$ & $\begin{array}{l}3 \\
7\end{array}$ \\
\hline $\begin{array}{l}\text { Lymphocytic leukemia } \\
\text { Aleukemic } \\
\text { Leukemic }\end{array}$ & $\begin{array}{l}3 \\
2\end{array}$ & $\begin{array}{l}0 \\
0\end{array}$ & $\begin{array}{l}3 \\
2\end{array}$ \\
\hline Polycythemia vera & 8 & 0 & 8 \\
\hline Hodgkin's disease & 4 & 0 & 4 \\
\hline Normal laboratory personnel & 20 & 0 & 20 \\
\hline Totals & 112 & 27 & 85 \\
\hline
\end{tabular}



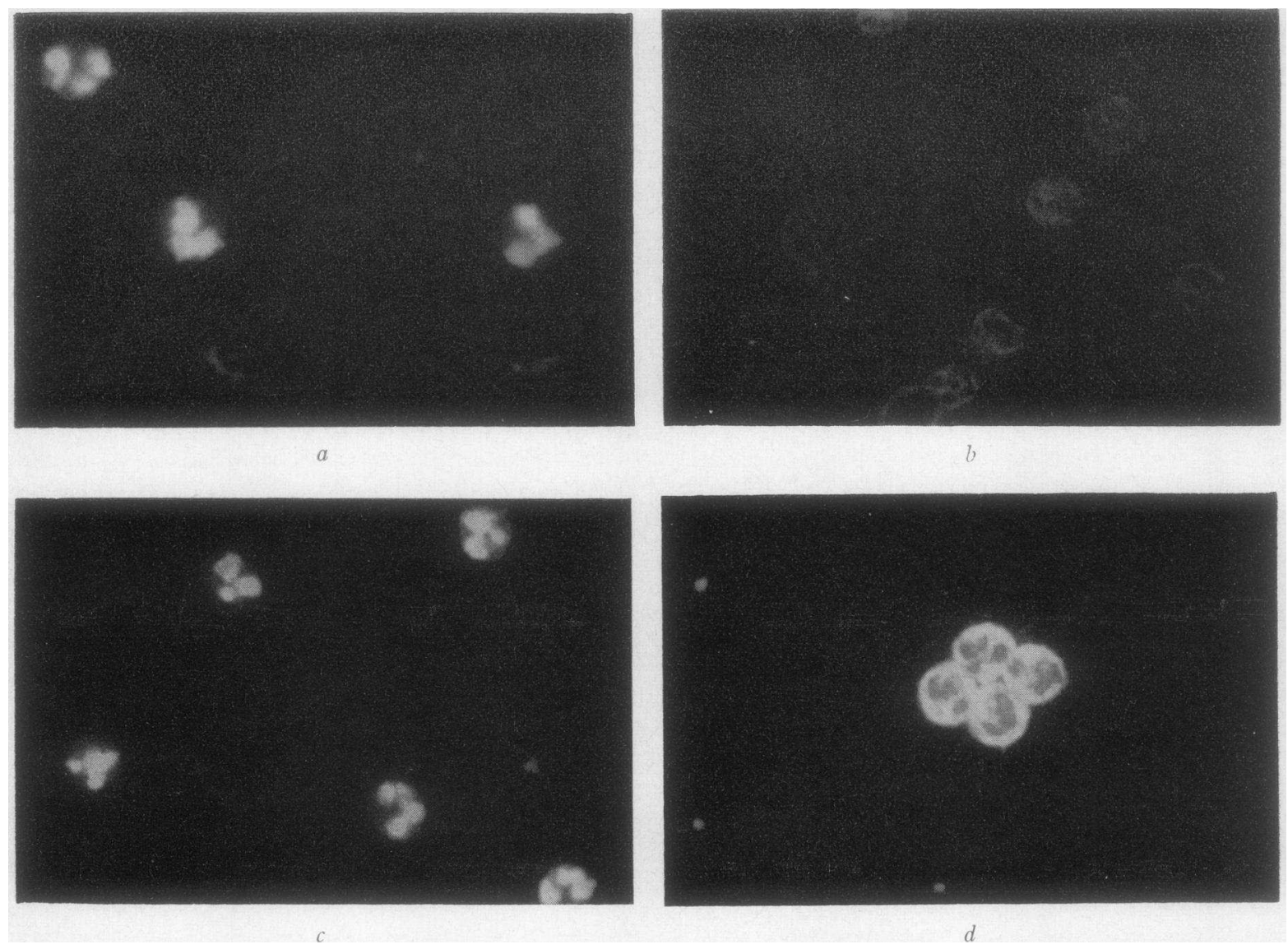

Fig. 1. Photomicrographs of Polymorphonuclear Leukocytes From Normal Blood Smears Treated With Human Sera and Superimposed With Fluorescein-Labeled Rabbit Antihuman Globulin (Coombs') SERUM

Human sera from: a) systemic lupus erythematosus; b) normal control; $c$ ) Felty's syndrome; $d$ ) normal control exposed to antiglobulin not absorbed with rabbit bone marrow. Note nonspecific cytoplasmic fluorescence.

us, except where otherwise indicated. The different disease states investigated are listed in Table I.

Preparation of fluoresient antihuman globulin (Coombs') serum. Human $\gamma$-globulin (Cohn Fraction II) in Freund's adjuvant (32) was injected intramuscularly into $3 \mathrm{Kg}$. male albino rabbits. The dosage schedule was $50 \mathrm{mg}$. of $\gamma$-globulin on four successive days of each week for four weeks with a repeat series after a two week interval. The animals were sacrificed seven days following the last injection. The sera with precipitin titers varying from $1: 40,000$ to $1: 80,000$ were pooled and stored at $-20^{\circ} \mathrm{C}$.

The fluorescein ${ }^{1}$ conjugate was prepared by the method described by Coons and Kaplan (30) with the following modification. The rabbit serum was precipitated twice with a half saturated ammonium sulfate solution, resuspended in $0.15 \mathrm{M} \mathrm{NaCl}$ and dialyzed against a solu-

1 The fluorescein amine was kindly supplied by Dr. Leland Pence, of Difco Laboratories. tion of $0.15 \mathrm{M} \mathrm{NaCl}$ containing $0.01 \mathrm{M}$ phosphate until no sulfate was detectable (usually four to six days) before conjugation with fluorescein isocyanate. The precipitation and dialysis were carried out at $4^{\circ} \mathrm{C}$.

The labeled conjugate was stored in 5 to $10 \mathrm{ml}$. aliquots at $-20^{\circ} \mathrm{C}$. and was absorbed twice with acetonedried rabbit bone marrow $(33,34)$ before use.

Testing procedure. A few drops of the human serum to be tested were placed on a thin portion of the slide in direct contact with the fixed normal blood smear and allowed to stand at room temperature in a moist chamber for one hour. The slide was then washed in running tap water for at least 30 minutes and air dried. The labeled rabbit antihuman globulin serum (Coombs' serum) was then superimposed on the test area of the smear for one hour under the same conditions. Vigorous washing for one hour or more was necessary to remove nonspecific labeling, and an even clearer differentiation was obtained if the preparations were allowed to stand 24 hours before making the observations by ultraviolet microscopy. 
Readings. All slides were read "blind" by each one of the authors. Early in the study, as many as five separate readings were done by each observer on different days, and some sera were tested on multiple occasions against smears from six or more individuals of different blood groups. It soon became apparent, however, that consistent results were being regularly obtained, and as our experience increased, two readings apiece were considered sufficient. For the sake of uniformity, only smears from $\mathrm{O} R$ h-negative normals were used in the latter part of the study, although definite, naturally occurring leukocyte isoantibodies could not be demonstrated and no specific relationship to erythrocyte antigens was observed $(1,23,35-37)$. An important aspect of the interpretation rests upon having a known positive serum and a known negative serum included in each series of slides stained. The presence or absence of the apple-green (specific) fluorescence constituted a positive or negative reading.

Microscopy and photographic equipment. A Leitz Ortholux microscope with a cardioid dark field condenser was used, with a 150 watt Philips mercury vapor lamp providing the ultraviolet light source. Thirty-five $\mathrm{mm}$. daylight super Anscochrome ${ }^{\circledR}$ film was used for recording the slides.

Lupus erythematosus (L.E.) cell preparations and sheep cell hemagglutination titers. L.E. cell preparations were performed by the method of Magath and Winkle (38). The sheep cell hemagglutination titers were carried out as described by Craig, Kerby and Persons (39).

In vivo studies. Whole blood was collected in vacuum bottles containing acid citrate dextrose (ACD) solution and, after centrifuging, the plasma was transferred to vacuum containers under aseptic conditions and stored at $-20^{\circ}$ C. until ready for use. The recipients were $\mathrm{ABO}$ and $\mathrm{Rh}$-compatible patients with far advanced neoplasms not obviously involving the bone marrow and with normal peripheral leukocyte counts. In each case the recipient was given first the plasma from a leukopenic subject and, several days later, a similar amount of normal plasma under identical conditions.

\section{RESULTS}

\section{Nonspecificity of unabsorbed fluorescent antihu- man globulin (Coombs') serum}

The use of labeled antihuman globulin serum which had not been absorbed with acetone-dried rabbit bone marrow caused cytoplasmic fluorescence of leukocytes previously exposed to normal serum (Figure $1 d$ ). This made the differentiation of positive and negative smears extremely difficult or impossible. After absorption with rabbit bone marrow, however, this nonspecific cytoplasmic labeling diminished markedly (Figure $1 b)$, allowing recognition of unequivocal differ- ences between cell nuclei coated with positive and negative sera (Figures $1 a, 1 b$, and $1 c$ ).

\section{Specificity of absorbed antihuman globulin (Coombs') serum}

To demonstrate the specificity of the labeled conjugate for human globulin, nonfluorescent rabbit antihuman globulin serum was superimposed on blood smears previously exposed to known positive sera from patients with SLE or Felty's syndrome. After subsequent exposure to labeled conjugate, the nuclei showed no fluorescence.

\section{Systemic lupus erythematosus, rheumatoid ar-} thritis and allied disorders

Fifteen patients with SLE were studied (Table II). In each case a strongly positive nuclear fluorescence was obtained by the technique described (Figure 1a). No difference was observed when smears of several individuals of various blood groups were used. All except one had positive L.E. cell tests at the time the fluorescein. test was performed. One patient (C.S.) was of special interest because of a positive nuclear fluorescence reading with absence of demonstrable L.E. cells. Her clinical picture was quite compatible with SLE and on subsequent examination, two months later, several positive L.E. preparations were obtained with her serum.

The sera of 23 patients with the clinical picture of rheumatoid arthritis were obtained (Table II). In 10 of these a clinical diagnosis of Felty's syndrome was made and, for the purposes of the discussion, this group will be considered separately. In general this "label" was used when the classic triad of leukopenia, splenomegaly and rheumatoid arthritis was present without serological or other clinical manifestations of SLE. The following exceptions or variations to this picture were present. Four patients with Felty's syndrome were studied post splenectomy and, though previously leukopenic, their total leukocyte counts were normal at this time. Splenomegaly was, or had been, present in all but two cases; one of these (I.B.) was the only patient in this group with a positive L.E. cell test. She had a documented history of rheumatoid arthritis for 26 years with classical, severe joint changes, and at no time had any evidence of serositis, nephritis, carditis or 
TABLE II

Patients with systemic lupus erythematosus, Felty's syndrome and rheumatoid arthritis

\begin{tabular}{|c|c|c|c|c|c|c|c|c|}
\hline Patient & $\begin{array}{l}\text { Age } \\
\text { and } \\
\text { sex }\end{array}$ & $\begin{array}{c}\text { Clinical } \\
\text { diagnosis }\end{array}$ & Splenomegaly & $\begin{array}{l}\text { WBC } \\
\times 10^{3}\end{array}$ & $\begin{array}{l}\text { Serum } \\
\text { proteins } \\
\text { A/G }\end{array}$ & $\begin{array}{c}\text { Sheep } \\
\text { cell } \\
\text { titers }\end{array}$ & $\begin{array}{l}\text { L.E. } \\
\text { prep. }\end{array}$ & $\begin{array}{l}\text { Nuclear } \\
\text { fluor. }\end{array}$ \\
\hline \multicolumn{9}{|c|}{$\mathrm{Gm} . / 100 \mathrm{ml}$} \\
\hline 1. A. T. & $39 \mathrm{~F}$ & SLE & Not Palp. & 5.8 & $3.4 / 5.5$ & $1: 20$ & + & + \\
\hline 2. S. C. & $31 \mathrm{~F}$ & SLE & Not Palp. & 5.0 & $4.5 / 3.4$ & Neg. & + & + \\
\hline 3. C. S. & $52 \mathrm{~F}$ & SLE & Not Palp. & 3.8 & $4.3 / 5.5$ & $1: 320$ & Neg.* & + \\
\hline 4. H. N. & $33 \mathrm{~F}$ & SLE & Not Palp. & 5.8 & $3.0 / 4.4$ & $1: 200$ & + & + \\
\hline 5. I. L. & $58 \mathrm{~F}$ & SLE & Not Palp. & 3.3 & $2.6 / 3.4$ & $1: 1600$ & + & + \\
\hline 6. B. M. & $15 \mathrm{~F}$ & SLE & Not Palp. & 5.4 & $1.9 / 5.6$ & Neg. & + & + \\
\hline 7. L. T. & $46 \mathrm{~F}$ & SLE & Not Palp. & 5.5 & $4.5 / 3.6$ & Neg. & + & + \\
\hline 8. D. Mi. & $22 \mathrm{~F}$ & SLE & Not Palp. & 6.0 & $4.3 / 3.6$ & $1: 80$ & + & + \\
\hline 9. D. Me. & $32 \mathrm{~F}$ & SLE & Not Palp. & 14.0 & $3.4 / 5.0$ & Neg. & $t$ & + \\
\hline 10. R. D. & $44 \mathrm{~F}$ & SLE & Not Palp. & 3.1 & $2.7 / 3.9$ & & + & + \\
\hline 11. J. D. & $18 \mathrm{~F}$ & SLE & Not Palp. & 3.4 & $1.2 / 2.3$ & & + & + \\
\hline 12. M. G. & $15 \mathrm{~F}$ & SLE & Not Palp. & 4.5 & $3.1 / 2.3$ & $1: 20$ & + & + \\
\hline 13. D. B. & $31 \mathrm{M}$ & SLE & $3 \mathrm{~cm}$ & 7.1 & $3.8 / 5.3$ & $1: 20$ & + & + \\
\hline 14. G. N. & $62 \mathrm{M}$ & SLE & Not Palp. & 4.9 & $2.8 / 4.6$ & $1: 80$ & + & + \\
\hline 15. B. V. & $25 \mathrm{~F}$ & SLE & Not Palp. & 7.5 & $4.3 / 4.3$ & $1: 20$ & + & + \\
\hline 1. I. B. & $59 \mathrm{~F}$ & Felty's & Not Palp. & 3.0 & $3.0 / 3.2$ & $1: 400$ & + & + \\
\hline 2. R. S. & $65 \mathrm{M}$ & Felty's & $10 \mathrm{~cm}$ & 1.0 & $2.8 / 4.1$ & $1: 80$ & Neg. & + \\
\hline 3. B. $\mathrm{H}$. & $79 \mathrm{~F}$ & Felty's & $4 \mathrm{~cm}$ & 1.2 & $3.7 / 3.9$ & Neg. & Neg. & + \\
\hline 4. E. B. & $66 \mathrm{M}$ & Felty's & Not Palp. & 2.8 & $4.7 / 3.4$ & $1: 1280$ & Neg. & + \\
\hline 5. K. F. & $70 \mathrm{~F}$ & Felty's & By X-ray & 0.8 & $3.2 / 4.0$ & $1: 80$ & Neg. & + \\
\hline 6. H. L.† & $55 \mathrm{~F}$ & Felty's & $4 \mathrm{~cm}$ & 2.2 & & $1: 320$ & Neg. & + \\
\hline 7. H. C. & $47 \mathrm{~F}$ & Felty's & \multirow{6}{*}{$\begin{array}{c}10 \mathrm{~cm} . \\
(1958) \ddagger \\
3 \mathrm{~cm} . \\
(1953) \ddagger \\
5 \mathrm{~cm} . \\
(1958) \ddagger \\
3 \mathrm{~cm} . \\
(1953) \ddagger\end{array}$} & \multirow{6}{*}{$\begin{array}{l}0.8 \\
6.6 \S \\
1.6 \\
6.6 \S \\
1.7 \\
8.9 \S \\
1.4 \\
5.6 \S\end{array}$} & \multirow{4}{*}{$\begin{array}{l}2.8 / 3.0 \\
2.6 / 1.9 \S \\
3.6 / 4.8 \\
3.7 / 3.7 \S \\
3.9 / 3.9\end{array}$} & $1: 5120$ & Neg. & + \\
\hline $8 \mathrm{~L} \quad \mathrm{M}$ & $58 \mathrm{~F}$ & Felty's & & & & $1: 2560 \S$ & Neg.§ & $+\S$ \\
\hline 8. L. MI. & $38 \mathrm{~F}$ & & & & & $1: 640 \S$ & Neg. $\S$ & $+\S$ \\
\hline 9. T. Mc. $†$ & $65 \mathrm{M}$ & Felty's & & & & & Neg. & \\
\hline 10. L. Mc. & $61 \mathrm{~F}$ & Felty's & & & $5.1 / 3.3$ & $1: 160 \S$ & Neg. $\S$ & $+\S$ \\
\hline 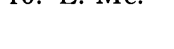 & 011 & $1010 \mathrm{y}$ & & & $4.5 / 3.18$ & $1: 40 \S$ & Neg.§ & $+\S$ \\
\hline 1. L. B. & $54 \mathrm{~F}$ & Rh. Arth. & Not Palp. & 5.0 & $3.7 / 3.0$ & $1: 320$ & Neg. & + \\
\hline 2. H. W. & $33 \mathrm{M}$ & Rh. Arth. & Not Palp. & 6.8 & $4.7 / 3.4$ & $1: 1280$ & Neg. & + \\
\hline 3. C. V. & $35 \mathrm{M}$ & Rh. Arth. & Not Palp. & 10.0 & $4.3 / 2.1$ & $1: 2560$ & Neg. & Neg. \\
\hline 4. C. D. & $54 \mathrm{M}$ & Rh. Arth. & Not Palp. & 7.8 & $4.1 / 2.6$ & $1: 1500$ & Neg. & Neg. \\
\hline 5. A. J. & $71 \mathrm{M}$ & Rh. Arth. & Not Palp. & 8.5 & $4.0 / 3.6$ & $1: 160$ & Neg. & Neg. \\
\hline 6. L. S. & $27 \mathrm{~F}$ & Rh. Arth. & Not Palp. & 8.5 & $3.9 / 2.3$ & $1: 40$ & Neg. & Neg. \\
\hline 7. M. J. & $57 \mathrm{~F}$ & Rh. Arth. & Not Palp. & 6.5 & $2.6 / 3.0$ & $1: 320$ & Neg. & Neg. \\
\hline 8. W. M. & $60 \mathrm{M}$ & Rh. Arth. & Not Palp. & 7.4 & $4.7 / 2.2$ & $1: 20$ & & Neg. \\
\hline 9. C. Mc. & $55 \mathrm{M}$ & Rh. Arth. & Not Palp. & 7.8 & $4.2 / 2.4$ & & Neg. & Neg. \\
\hline 10. H. S. & $50 \mathrm{~F}$ & Rh. Arth. & Not Palp. & 8.5 & $4.9 / 2.2$ & $1: 320$ & Neg. & Neg. \\
\hline 11. M. D. & $56 \mathrm{~F}$ & Rh. Arth. & Not Palp. & 12.0 & & $1: 20$ & Neg. & Neg. \\
\hline 12. H. B. & $66 \mathrm{M}$ & Rh. Arth. & Not Palp. & 11.5 & & Neg. & Neg. & Neg. \\
\hline 13. G. H. & $65 \mathrm{M}$ & Rh. Arth. & Not Palp. & 6.3 & $4.1 / 2.6$ & $1: 1280$ & Neg. & Neg. \\
\hline
\end{tabular}

* Negative at time of positive fluorescent antiglobulin test. Two months later positive L.E. preps.

† We are grateful to Dr. W. C. Moloney, Boston, Mass. for allowing us to study this patient.

$\ddagger$ Date of splenectomy.

$\S$ Postsplenectomy determinations.

Blank spaces, no determination performed.

dermatitis. Hemolytic anemia and thrombocytopenia were absent and the serological test for syphilis (VDRL) was negative. She had received infrequent small doses of steroids intermittently since 1954 .

The sera from each of these 10 patients produced strong nuclear fluorescence which resembled in all respects the response obtained with the sera from the patients with SLE (Figures $1 a$ and $1 c$ ). The presence of positive nuclear fluorescence tests in four patients (L.M., L.Mc., T.Mc. and H.C.) for periods up to five years after splenectomy, in the presence of normal leukocyte counts, is of particular interest.

Of the remaining 13 patients with uncomplicated rheumatoid arthritis, the sera from two 
contained a factor which caused nuclear fluorescence. None of these patients had positive L.E. cell tests.

A group of eight patients with other forms of possibly related disorders, all without splenomegaly or leukopenia and with negative L.E. cell tests, showed negative results with the fluorescent staining technique (Table I).

Nonrheumatic patients with hyperglobulinemia or on steroid therapy

To test the possibility that hyperglobulinemia per se may produce a positive reaction, the sera of seven patients with elevated globulins were tested. Three of these had Laennec's cirrhosis with globulins ranging from 3.0 to $3.8 \mathrm{Gm}$. per $100 \mathrm{ml}$. Three had multiple myeloma with globulins of 5.9, 11.2 and $11.3 \mathrm{Gm}$. per $100 \mathrm{ml}$., respectively, and one patient with bronchogenic carcinoma had a globulin of $4.6 \mathrm{Gm}$. per $100 \mathrm{ml}$. The fluorescent antiglobulin test was negative in all.

To exclude a possible effect of steroid therapy on the mechanism of the test, the sera of three patients with chronic bronchial asthma were tested. All had been receiving significant doses of steroids for at least three years and all showed negative results.

\section{Patients receiving multiple transfusions}

The sera from four patients who had received multiple transfusions were studied. Three of these patients had received 80,97 and 232 transfusions, respectively, and two of them experienced repeated, nonhemolytic, febrile reactions. The serum from the fourth patient was known to contain a powerful leukoagglutinin. ${ }^{2}$ A noticeable increase of leukocyte fluorescence was observed in all. The location of this was at first interpreted to be nuclear (31), but with the greater magnification and better resolution of the microscopic equipment now available to us, it is clear that all the fluorescence is confined to the cytoplasm.

\section{Idiopathic thrombocytopenic purpura}

Because it is known that destructive processes of the three formed elements of the peripheral

${ }^{2}$ We are grateful to Dr. T. E. Brittingham, St. Louis, Mo., for sending us this serum. blood may on occasions show multiple involvement $(1,4,13,40)$, sera from five patients with idiopathic thrombocytopenic purpura were studied for evidence of antileukocyte globulins. Leukocyte fluorescence was negative in all cases, but particularly striking platelet fluorescence was observed in one case. This suggests the possibility of developing a similar fluorescent antiglobulin test for platelets.

\section{Leukemias, polycythemia vera and Hodgkin's disease}

A total of 27 patients with these disorders were studied, including six cases with aleukemic leukemia (Table I). In none was the presence of antileukocyte factors demonstrated by the present technique.

\section{In vivo studies}

Three hundred fifty ml. of I.B.'s plasma and $250 \mathrm{ml}$. of R.S.'s plasma, both with clinically diagnosed Felty's syndrome, were administered to two hematologically normal recipients. Within 15 minutes from the beginning of the infusion a significant fall of the total leukocyte count was observed in each recipient (Figure $2 a$ ). There was no selective depression of either granulocytes or mononuclear cells. In one case (plasma from I.B.), the transfusion was followed by shaking chills for 45 minutes, accompanied by an urge to urinate, and in both instances the recipients experienced a transient temperature elevation to $100^{\circ}$ and $101^{\circ} \mathrm{F}$., respectively (Figure $2 a$ ). Identical infusions of normal plasma administered two days following each experiment produced no systemic reaction or significant change in leukocyte count in either recipient (Figure $2 b$ ). The infusion of $250 \mathrm{ml}$. of plasma from A.T. (SLE) into a control recipient produced no significant change in the leukocyte count.

\section{DISCUSSION}

The study of leukocyte immunology in clinical investigations has been based chiefly on the in vitro demonstration of leukoagglutinins and in vivo transfusion or transplacental (41) transfer of antileukocyte factors. The problems and inaccuracies of the first method stem mainly from the difficulty in preparing adequate leukocyte 


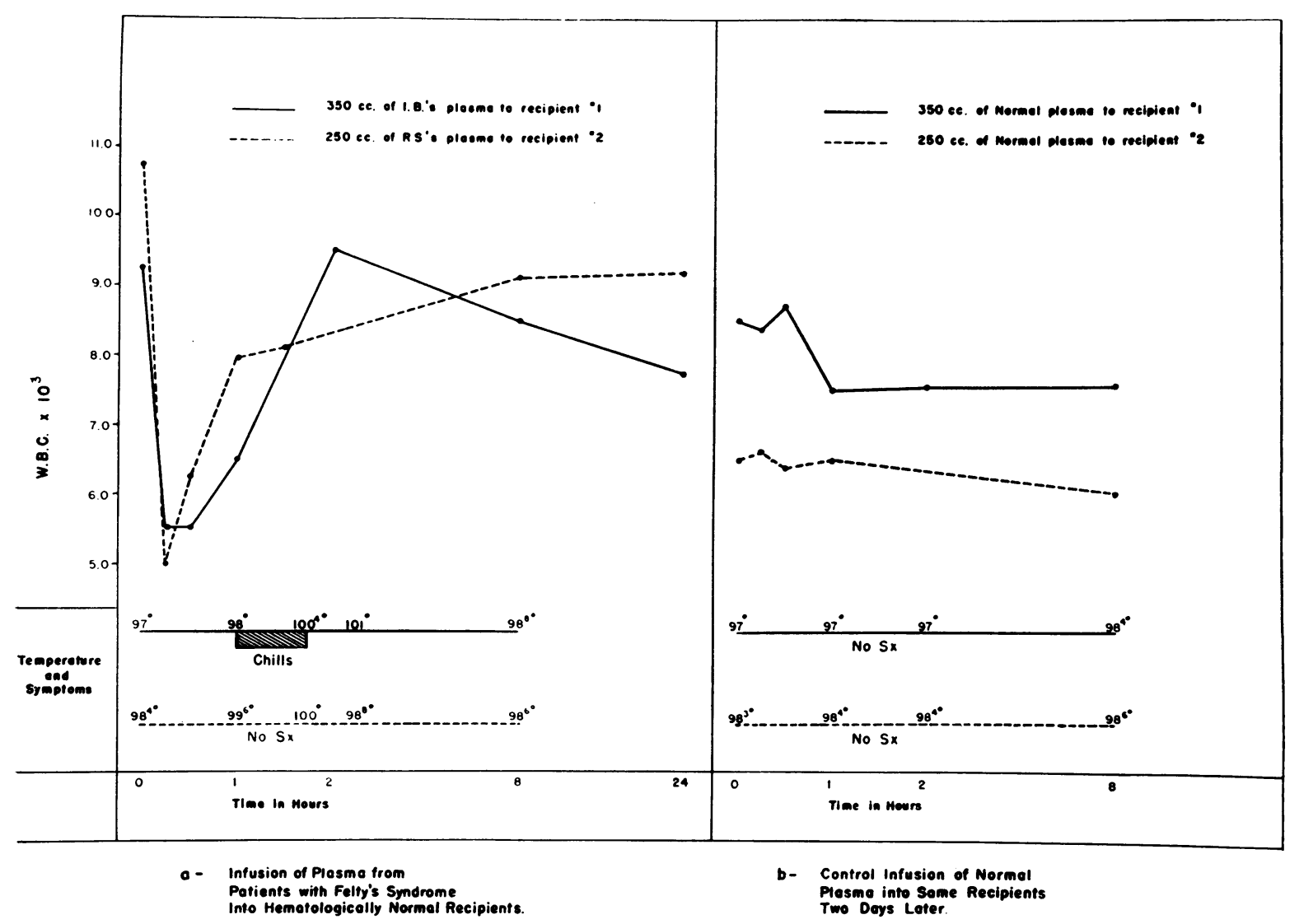

Fig. 2. Results of Plasma Infusions

In all cases the infusions were begun at zero time. They were terminated at 30 minutes in recipient No. 1 and at 60 minutes in recipient No. 2 .

suspensions without causing injury and hence alteration of the cell surface, which results in false positive agglutination (6). In addition, agglutinations may occur from fibrinogen adsorbed on the surface of normal leukocytes (42), from leukergy (43), as well as from red and white cell clumps either secondary to erythrophagocytosis $(28,35)$ or nonspecific cellular adherence (44). The hazards (23) and inherent limitations of the in vivo studies preclude their extensive use in clinical practice. Neither technique is readily applicable to the study of autoimmune leukopenia or to the demonstration of incomplete and cell-bound leukocyte antibodies (25). Finally, it is difficult with either method to differentiate between immunologic factors directed against the various types of leukocytes, and both fail to detect specifically antinuclear and anticytoplasmic factors. The fluorescent antiglobulin technique is theoretically capable of circumventing these difficulties.
The use of this technique for the study of leukocyte immunology has been hampered by the fact that nonspecific fluorescent staining of the leukocyte cystoplasm occurs with labeled rabbit antihuman globulin (Coombs') serum $(29,33,34$, 45). The precise mechanism of this phenomenon is not clear, but it may be due to nonspecific adsorption of plasma proteins on the hydrophilic polar surface of the leukocytes (42). In our hands, nonspecific fluorescence occurring with untreated labeled antiglobulin made the differentiation of positive from negative preparations very difficult and often impossible. However, absorption of the labeled conjugate with acetone-dried rabbit bone marrow before use $(33,34)$ greatly diminishes or entirely eliminates the nonspecific cytoplasmic fluorescence (compare Figures $1 b$ and $1 d)$. This step greatly facilitates the detection of specific antinuclear reactions by providing definite contrast between nuclear fluorescence and cyto- 
plasmic background (Figures $1 a$ and 1c). Furthermore it may prove valuable in studying specific anticytoplasmic substances which could not be otherwise accurately quantified in the presence of this coexisting nonspecific fluorescence. Although an increased cytoplasmic localization was present when absorbed antiglobulin was superimposed on the sera of patients receiving multiple transfusions, it is evident that further carefully controlled studies are required to ascertain whether this observed difference is reproducible.

Previous animal experiments $(46,47)$ have indicated that two types of heteroimmune granulocyte antibodies may be produced. One of these is directed against the cytoplasm and may be obtained by injecting intact cells (47), whole cytoplasm $(46,48)$ or cytoplasmic fractions $(46,49)$. The antiserum thus produced appears to promote ingestion of the intact granulocyte with lytic effects upon the cytoplasm $(46,47)$ and is said to be specific for leukocytes (46). The other type of antibody may be produced by injecting nuclear material from granulocytes (48) or other tissues and hence appears to be relatively nonspecific (46). Although administration of this antiserum to animals produces a much less pronounced granulocytopenia than anticytoplasmic serum (48), when combined with normal granulocytes it is capable of producing "L.E.-like" cells (46). It has been recently reported by Friou, Finch and Detre (50) and Holman and Kunkel (51) that the fluorescent antiglobulin technique could be employed to demonstrate the interaction of the serum L.E. factor and cell nuclei and nucleoprotein. Moreover, it appears that nuclear material from many different species and varying human tissues can be made to participate in this reaction ( 45 , 50-53). Our results have confirmed the work reported by others indicating the affinity of the serum of patients with SLE for leukocyte nuclei. Furthermore, in one instance, this test has proven more sensitive than the conventional L.E. cell preparation, anticipating the demonstration of the latter by at least two months. A similar case, with letection of "lupus globulin" preceding the L.E. cell test by two years, has recently been reported in detail by Friou (54).

Since 1924, when Felty (55) first described a syndrome consisting of leukopenia, splenomegaly and arthritis, there has been much speculation re- garding the nature of this entity and the cause of the leukopenia. It is generally accepted that this represents a variant of rheumatoid arthritis (5658). The leukopenia, often a neutropenia, has been variously attributed to chronic infection (57), hypersplenism $(56,58-60)$, leukocyte agglutinins (17) or unknown causes (61). It is well recognized that a positive L.E. cell test can be obtained in rheumatoid arthritis (54,62-64), particularly in Felty's syndrome (65). In addition, the presence of small quantities of "lupus globulin" has been detected in patients with rheumatoid arthritis (54). The finding of positive nuclear fluorescence in 12 of our cases of rheumatoid arthritis is therefore not entirely unexpected. It is particularly noteworthy, however, that all 10 cases of Felty's syndrome, without exception, showed a strongly positive reaction indistinguishable, by our method, from that seen with SLE. To our knowledge this has not been previously reported. This finding offers further evidence of a basic relationship in these disease processes and encourages speculation that we may be dealing with a similar pathologic entity with a wide spectrum of manifestations. Thus, Felty's syndrome may be a connecting link which lies somewhere between uncomplicated rheumatoid arthritis and SLE.

Some authors have considered that the L.E. factor may be responsible for the development of the leukopenia commonly seen in $\operatorname{SLE}(46,66)$. We would like to suggest that an antinuclear globulin may also be partly responsible for the leukopenia seen in Felty's syndrome. Further evidence that an antileukocyte factor in Felty's syndrome may be involved in the pathogenesis of the leukopenia was obtained from in vivo experiments. Definite, immediate, transient depressions of the leukocyte count accompanied by chills and fever, were obtained upon transfusion of 250 and $350 \mathrm{ml}$. of sera containing this factor. The quality and duration of this response are similar to those described by others $(4,6,17,67-69)$. Presumably the fever was secondary to the release of tissue pyrogens from destroyed leukocytes $(6,70$, $71)$; however, notwithstanding sterile cultures, the possible presence of bacterial pyrogens cannot be entirely excluded (72).

Recent work has demonstrated that patients who have received multiple transfusions may de- 
velop leukoagglutinins $(23,68,73)$ or incomplete white cell antibodies (74) in their sera. Moreover, isoimmunization of a normal subject has been achieved by repeated injection of leukemic blood (23). The practical importance of this phenomenon in producing febrile transfusion reactions has been stressed, and their prevention by removal of leukocytes prior to transfusion is advocated (22, $68,75)$. If an inference can be drawn from the previously discussed animal experiments (46-49), it would seem reasonable to find that these presumed human leukocyte isoantibodies are primarily directed against cytoplasmic antigens.

There are many other conditions in which antileukocyte substances have been demonstrated or suspected. The application of the fluorescent antiglobulin technique for the study of sera from such patients should be of help in elucidating the mechanisms of the leukopenia, the type of cells involved, the character of the substances responsible and their location on the cell.

\section{SUM MARY}

A method for studying leukocyte immunology by the fluorescent antiglobulin technique is described.

The results with sera from various disease states are reported. The data presented are consistent with the concept that human antileukocyte globulins may be directed against the nucleus or against the cytoplasm.

Antinuclear globulins were detected in the sera of all patients with systemic lupus erythematosus (SLE) and Felty's syndrome studied, and in two cases of apparently uncomplicated rheumatoid arthritis. These findings suggest that Felty's syndrome may be a connecting link of a disease spectrum involving simple rheumatoid arthritis and SLE.

Evidence that a circulating factor present in patients with Felty's syndrome may be involved in the pathogenesis of the leukopenia was obtained in two instances by plasma transfusions.

\section{REFERENCES}

1. Dausset, J., Nenna, A., and Brecy, H. Leukoagglutinins. V. Leukoagglutinins in chronic idiopathic or symptomatic pancytopenia and in paroxysmal nocturnal hemoglobinuria. Blood 1954, 9, 696.
2. Tullis, J. L. Prevalence, nature and identification of leukocyte antibodies. New Engl. J. Med. 1958, 258, 569.

3. Walford, R. L., Peterson, E. T., and Doyle, P. Leukocyte antibodies in human sera and in immune rabbit sera. Blood 1957, 12, 953.

4. Moeschlin, S., Siegenthaler, W., Gasser, C., and Hässig, A. Immunipancytopenia associated with incomplete cold hemagglutinins in a case of primary atypical pneumonia. Blood 1954, 9, 214.

5. Martensson, J., and Vikbladh, I. Idiopathic immunoneutropenia. Report of a case with a leukocyte agglutinating factor in the serum. Blood 1954, 9, 632.

6. Butler, J. J. Chronic idiopathic immunoneutropenia. Amer. J. Med. 1958, 24, 145.

7. Harrington, W. J., Minnich, V., Hollingsworth, J. W., and Moore, C. V. Demonstration of thrombocytopenic factor in blood of patients with thrombocytopenic purpura. J. Lab. clin. Med. 1951, 38,1 .

8. Harrington, W. J., Sprague, C. C., Minnich, V., Moore, C. V., Aulvin, R. C., and Dubach, R. Immunologic mechanisms in idiopathic and neonatal thrombocytopenic purpura. Ann. intern. Med. 1953, 38, 433.

9. Stefanini, M., Dameshek, W., Chatterjea, J. B., Adelson, E., and Mednicoff, I. B. Studies on platelets. IX. Observations on the properties and mechanism of action of a potent platelet agglutinin, detected in the serum of a patient with idiopathic thrombocytopenic purpura. Blood 1953, 8, 26.

10. Weiner, W., Battey, D. A., Cleghorn, T. E., Marson, F. G. W., and Meynell, M. J. Serological findings in a case of haemolytic anemia with some general observations on the pathogenesis of this syndrome. Brit. med. J. 1953, 2, 125.

11. Boorman, K. E., Dodd, B. E., and Loutit, J. F. Hemolytic icterus (acholuric jaundice) congenital and acquired. Lancet 1946, 250, 812.

12. Evans, R. S., and Weiser, R. S. The serology of autoimmune hemolytic disease. Arch. intern. Med. 1957, 100, 371.

13. Wasastjerna, C. Leukocyte-agglutinins in a case of chronic granulocytopenia and hemolytic anemia. Acta med. scand. 1954, 149, 355.

14. Harris, J. W. Studies on the mechanism of a druginduced hemolytic anemia. J. Lab. clin. Med. 1956, 47, 760 .

15. Ackroyd, J. F. The pathogenesis of thrombocytopenic purpura due to hypersensitivity to sedormid. Clin. Sci. 1949, 7, 249.

16. Bolton, F. G., and Young, R. V. Observations on cases of thrombocytopenic purpura due to quinine, sulphamezathine and quinidine. J. clin. Path. 1953, 6, 320 .

17. Moeschlin, S., and Wagner, K. Agranulocytosis due to the occurrence of leukocyte-agglutinins (pyramidon and cold agglutinins). Acta haemat. (Basel) 1952, 8, 29. 
18. Wintrobe, M. M., and Cartwright, G. E. Blood disorders caused by drug sensitivity. Arch. intern. Med. 1956, 98, 559.

19. Koszewski, B. J., and Hubbard, T. F. Immunologic agranulocytosis due to mercurial diuretics. Amer. J. Med. 1956, 20, 958.

20. Moeschlin, S., Meyer, H., Israels, L. E., and TarrGloor, E. Experimental agranulocytosis. Its production through leukocyte agglutination by antileukocytic serum. Acta haemat. (Basel) 1954, 11, 73.

21. Dausset, J. Leuco-agglutinins. IV. Leuco-agglutinins and blood transfusion. Vox Sang. (Basel) 1954, 4, 190.

22. Payne, R. The association of febrile transfusion reactions with leuko-agglutinins. Vox Sang. (Basel) 1957, 2, 233.

23. Brittingham, T. E. Immunologic studies on leukocytes. Vox Sang. (Basel) 1957, 2, 242.

24. Seligmann, M., Grabar, P., and Bernard, J. Leucoprecipitins. I. Presence of precipitating antileucocyte antibodies in the serum of patients with acute leukemia. Vox Sang. (Basel) 1954, 4, 181.

25. Killmann, S. Leukocyte-auto-agglutinin in a case of acute monocytic leukemia. Acta haemat. (Basel) 1957, 17, 360.

26. Andre, R., Dreyfus, B., and Bessis, M. Anticorps antileucocytaire dans un cas de lucémie lymphoide. Aspect Hodgkinien de la rate. Influence de la splénectomie. Rev. Hémat. 1954, 9, 50.

27. Marchal, G., Duhamel, G., Dausset, J., and Libeskind, M. Apparition d'une leuco-agglutinine au cours d'une maladie de Hodgkin. Sem. Hôp. Paris 1954, 30, 4355.

28. Bakemeier, R. F., and Swisher, S. N. Mixed agglutination of leukocytes and erythrocytes in relation to studies of leukocyte antigens. Blood 1957, 12, 913.

29. Danaher, T. H., Friou, G. J., and Finch, S. C. Fluorescein labeled antiglobulin test applied to leukocyte immunology. Clin. Res. Proc. 1957, 5, 9.

30. Coons, A. H., and Kaplan, M. H. Localization of antigen in tissue cells. II. Improvements in a method for the detection of antigen by means of fluorescent antibody. J. exp. Med. 1950, 91, 1.

31. Calabresi, P., Edwards, E. A., and Schilling, R. F. Fluorescent antiglobulin studies in leukopenic and multiple transfusion disorders (abstract). J. Lab. clin. Med. 1958, 52, 801.

32. Freund, J., and Bonanto, M. V. The effect of paraffin oil, lanolin-like substances, and killed tubercle bacilli on immunization with diphtheric toxoid and Bact. typhosum. J. Immunol. 1944, 48, 325.

33. Coons, A. H., Leduc, E. H., and Connolly, J. M. Studies on antibody production. I. A method for the histochemical demonstration of specific antibody and its application to a study of the hyperimmune rabbit. J. exp. Med. 1955, 102, 49.
34. Sheldon, W. H. Leptospiral antigen demonstrated by the fluorescent antibody technic in human muscle lesions of Leptospirosis icterohemorrhagiac. Proc. Soc. exp. Biol. (N. Y.) 1953, 84, 165.

35. Butler, J. J. Some studies on the naturally occurring leukocyte agglutinins. J. clin. Invest. 1956, 35, 1150.

36. Moeschlin, S., and Schmid, E. Investigation of leukocyte agglutination in serum of compatible and incompatible blood groups. Acta haemat. (Basel) 1954, 11, 241.

37. Goudsmit, R., and VanLoghem, J. J., Jr. Studies on the occurrence of leucocyte-antibodies. Vox Sang. (Basel) 1953, 3, 3.

38. Magath, T. B., and Winkle, V. Technic for demonstrating "L.E." (lupus erythematosus) cells in blood. Amer. J. clin. Path. 1952, 22, 586.

39. Craig, H. W., Kerby, G. P., and Persons, A. L. Results of a modified rheumatoid hemagglutination test; correlation of results with occurrence of C-reactive protein. J. Lab. clin. Med. 1957, 49, 635.

40. Evans, R. S., Takahashi, K., Duane, R. T., Payne, R., and Liu, C. Primary thrombocytopenic purpura and acquired hemolytic anemia. Evidence for a common etiology. Arch. intern. Med. 1951, 87, 48.

41. Stefanini, M., Mele, R. H., and Skinner, D. Transitory congenital neutropenia: A new syndrome. Amer. J. Med. 1958, 25, 749.

42. Brittingham, T. Observations on mechanism and prevention of non-specific agglutination of leukocytes. Proc. Soc. exp. Biol. (N. Y.) 1958, 99, 252.

43. Fleck, L. Further investigations on the phenomenon of leukergy. Tex. Rep. Biol. Med. 1951, 9, 697.

44. Swisher, S. N. Nonspecific adherence of platelets and leukocytes to antibody sensitized red cells; a mechanism producing thrombocytopenia and leukopenia during incompatible transfusions in Proceedings of the Sixth International Congress of the International Society of Hematology. New York, Grune and Stratton, Inc., 1958, p. 896.

45. Holborow, E. J., Weir, D. M., and Johnson, G. D. A serum factor in lupus erythematosus with affinity for tissue nuclei. Brit. med. J. 1957, 2, 732.

46. Miescher, $P$. The antigenic constituents of the neutrophilic leukocyte with special reference to the L.E. phenomenon. Vox Sang. (Basel) 1957, 2, 145.

47. Finch, S. C., Ross, J. F., and Ebaugh, F. G. Immunologic mechanisms of leukocyte abnormalities. J. Lab. clin. Med. 1953, 42, 555.

48. Finch, S. C., Cajano, A., and Ross, J. F. Leukocyte response to leukocyte nuclear and cytoplasmic antisera. J. Lab. clin. Med. 1955, 46, 871.

49. Hollingsworth, J. W., and Finch, S. C. Leukocyte response to granulocyte fraction antisera. J. Lab. clin. Med. 1955, 46, 879. 
50. Friou, G. J., Finch, S. C., and Detre, K. D. Interaction of nuclei and globulin from lupus erythematosus serum demonstrated with fluorescent antibody. J. Immunol. 1958, 80, 324.

51. Holman, H. R., and Kunkel, H. G. Affinity between the lupus erythematosus serum factor and cell nuclei and nucleoprotein. Science 1957, 126, 162.

52. Mellors, R. C., Ortega, L. G., and Holman, H. R. Role of gamma globulins in the pathogenesis of renal lesions in systemic lupus erythematosus and chronic membranous glomerulonephritis, with an observation on the lupus erythematosus cell reaction. J. exp. Med. 1957, 106, 191.

53. Bardawil, W. A., Toy, B. L., Galins, N., and Bayles, T. B. Disseminated lupus erythematosus, scleroderma and dermatomyositis as manifestations of sensitization to DNA-protein. I. An immunohistochemical approach. Amer. J. Path. 1958, 34, 607.

54. Friou, G. J. The significance of the lupus globulinnucleoprotein reaction. Ann. intern. Med. 1958, 49, 866.

55. Felty, A. R. Chronic arthritis in the adult, associated with splenomegaly and leucopenia. A report of five cases of an unusual clinical syndrome. Bull. Johns Hopk. Hosp. 1924, 35, 16.

56. Hutchinson, H. E., and Alexander, W. D. Splenic neutropenia in the Felty syndrome. Blood 1954, 9, 986.

57. Curtis, A. C., and Pollard, H. M. Felty's syndrome: Its several features, including tissue changes, compared with other forms of rheumatoid arthritis. Ann. intern. Med. 1940, 13, 2265.

58. Hutt, M. S. R., Richardson, J. S., and Staffurth, J. S. Felty's syndrome. A report of four cases treated by splenectomy. Quart. J. Med. 1951, 20, 57.

59. Blau, J. N., and Willcox, J. Splenic neutropenia in Felty's syndrome. Brit. med. J. 1957, 2, 1094.

60. Steinberg, C. L. The value of splenectomy in Felty's syndrome. Ann. intern. Med. 1942, 17, 26.

61. Wintrobe, M. M. Clinical Hematology, 4th ed. Philadelphia, Lea and Febinger, 1956, p. 238.

62. McCoy, F. W., Patterson, M., and Freyberg, R. H. A study of disseminated lupus erythematosus in patients formerly considered to have rheumatoid arthritis. Ann. rheum. Dis. 1955, 14, 415.

63. Kievits, J. H., Goslings, J., Schuit, H. R. E., and Hijmans, W. Rheumatoid arthritis and the posi- tive L.E.-cell phenomenon. Ann. rheum Dis. 1956, 15, 211.

64. Ross, S. W., and Clardy, E. K. The L.E. test in patients presenting the clinical picture of rheumatoid arthritis. Sth. med. J. (Bgham, Ala.) 1956, 49, 553 .

65. Friedman, I. A., Sickley, J. F., Poske, R. M., Black, A., Bronsky, D., Hartz, W. H., Feldhake, C., Reeder, P. S., and Katz, E. M. The L.E. phenomenon in rheumatoid arthritis. Ann. intern. Med. 1957, 46, 1113.

66. Dameshek, W. Systemic lupus erythematosus: A complex auto-immune disorder. Ann. intern. Med. 1958, 48, 707.

67. Kissmeyer-Nielson, F., Bichel, J., and Bjerre-Hansen, P. Experimental investigations on the pathogenesis of non-leukemic and leukemic leukopenia. Acta med. scand. 1954, 150, 349.

68. Brittingham, T. E., and Chaplin, H., Jr. Febrile transfusion reactions caused by sensitivity to donor leukocytes and platelets. J. Amer. med. Ass. 1957, $165,819$.

69. Miescher, P. Leucopénie chronique par "auto-anticorps.” Acta haemat. (Basel) 1954, 11, 152.

70. Bennett, I. L., Jr., and Beeson, P. B. Studies on the pathogenesis of fever. II. Characterization of fever-producing substances from polymorphonuclear leukocytes and from fluid of sterile exudates. J. exp. Med. 1953, 98, 493.

71. Atkins, E., and Wood, W. B., Jr. Studies on the pathogenesis of fever. I. The presence of transferable pyrogen in the blood stream following the injection of typhoid vaccine. J. exp. Med. 1955, $101,519$.

72. Bennett, I. L., Jr., and Beeson, P. B. The properties and biologic effects of bacterial pyrogens. Medicine $1950,29,365$.

73. Payne, R. Leukocyte agglutinins in human sera. Arch. intern. Med. 1957, 99, 587.

74. Van Loghem, J. J., Jr., Van Der Hart, M., and Borstel, H. The occurrence of complete and incomplete white cell antibodies. Vox Sang. (Basel) 1957, 2, 257.

75. Dausset, J., Fonseca, A., and Brecy, H. Elimination de certains chocs transfusionnels par l'utilisation de sang appauvri en leucocytes. Vox Sang. (Basel) 1957, 2, 248. 